\title{
PEST INFESTATION RESEARCH
}

\begin{abstract}
$\mathrm{T}$ HE greater part of the report for 1955 on "Pest Infestation Research"* is devoted to the collected summaries of some ninety investigations in progress at the Department of Scientific and Indus. trial Research Pest Infestation Laboratory at Slough during 1955. Many of these investigations were continued from earlier years, and among those reaching completion last year was the detailed study of the behaviour of the carpet beetle. The complex life-cycle of this insect, which involves the deposition of eggs in birds' nests in the eaves of houses, is described and correlated with the mode of infestation. Other biological problems studied include the elucidation of the life-histories and physical limits of several species of beetles and mites which are important pests of foodstuffs.

Problems associated with the bulk storage of various types of grain formed a prominent part of the Laboratory's work. Field experiments on the use of underground grain-storage pits, originally started in Africa, were continued at Slough. The success of this method was found to be due to the rapid decrease in the oxygen concentration, which led to the death of the infesting insects.

Much of the work of the Insecticide Section is of immediate practical importance, being concerned with such problems as the insect penetration of multi-ply paper sacs, the toxicity of malathion to insects, the control of the cacao moth in warehouses and the assessment of spraying and dusting equipment. A major item in this Section's programme of work was an investigation on the means of controlling insect damage to stored groundnuts in Gambia. The chief damage was caused by the groundnut beetle (Coryedon fuscus), which attacks the surface layers in the piles of bulk-stored nuts, where up to $94 \cdot 5$ per

* Department of Scientific and Industrial Research. Report of the Pest Infestation Research Board with the Report of the Director of Pest Infestation Research for the year 1955. Pp. iv $+62+8$ plates. (London: H.M. Stationery Office, 1956.) 4s. net.
\end{abstract}

cent damage was reported after four months storage. Several experimental trials were initiated and a satisfactory degree of control was achieved using insecticidal dusts. Attempts to protect shelled nuts by using bags of various materials did not prove so successful.

The biochemical work of the Pest Infestation Laboratory was largely concerned with studies on the chemical reactions of insecticides with foodstuffs and with fundamental research into the mode of action of insecticides. A particular example of the latter is the investigation on the effects of DD'T on phosphorus metabolism in insects, which is likely to prove a valuable addition to our knowledge of the mechanism of insecticidal poisoning in insects. As the report points out, insect biochemistry remains a relatively unexplored field and much research on the normal insect is required before the biochemical effects of insecticidal action can be properly appreciated. It is gratifying to read, therefore, that a proportion of the biochemical work at Slough falls into this category.

An interesting development announced in the report is the proposal to form a pool of entomologists and chemists. The members of the pool will be attached to the Laboratory at Slough and will be available to visit the Colonial territories to undertake specific investigations as the need for them arises. This policy is of obvious importance to Great Britain in view of the large imports of raw foodstuffs, and it is clearly desirable to be able to control infestation at the source. Colonial liaison is, however, not a recent departure, for it has long been an important part of the work of the Pest Infestation Laboratory. During 1955 several investigations were in progress in various Colonial territories, and a great deal of the work done at Slough was directed towards solving problems of food storage in the Colonies.

J. E. TREHERNE

\section{VISUAL DEMONSTRATION OF ALLELIC DIFFERENCES WITHIN CELL NUCLEI}

\author{
By Prof. H. G. CALLAN and L. LLOYD \\ Department of Natural History, The University, St. Andrews
}

\begin{abstract}
$\mathrm{T}$ HE characteristic patterns of cross-banding on the salivary gland chromosomes of dipteran larva have been shown beyond reasonable doubt to reflect the linear genetic differentiation of these chromosomes. Some of the strongest evidence in favour of this view comes from the cytological study of chromosomes which, as a result of genetical experiment, have been supposed to possess gene arrangements differing from a standard sequence by inversion, translocation, duplication or deletion. Some of these structural rearrangements are associ-
\end{abstract}

ated with clear-cut phenotypic effects : of these, the 'Bar' mutants of Drosophila melanogaster ${ }^{1}$ were the first to be so recognized.

The great majority of Drosophila mutants cannot, however, be differentiated from wild-type flies when the salivary gland chromosomes of mutant and wild. type are compared. This is certainly not due to inadequate techniques or insufficiently painstaking studies: often enough the chromosome region in which a particular mutant gene is located has been very precisely known. 